\title{
Critical Thinking and Challenges for Education for Democratic Citizenship: an ethnographic study in primary schools in Greece
}

\author{
'London School of Economics (LSE), London-United Kingdom
}

ABSTRACT - Critical Thinking and Challenges for Education for Democratic Citizenship: an ethnographic study in primary schools in Greece. This article reports on an ethnographic multiple case study in Greece. It explores teachers' practices regarding the education of critically thinking citizens ten years into the implementation of an integrated curriculum reform. By means of classroom observations and semi-structured interviews this research explored the role of critical thinking in the classrooms. Findings suggest that teachers refrain from practices that advance critical thinking skills and pupils' empowerment. Instead they tend to implement traditional practices, while their work is largely determined by the standards of achievement set by University Entrance Exams and parents' aspirations. The article concludes that prevailing expectations in the Greek primary school interfere with the development of pedagogical relationships that would promote critical thinking obstructing the attainment of the aims of the integrated curriculum reform and compromising the project for democratic citizenship.

Keywords: Critical Thinking. Democratic Citizenship. Pedagogical Practice. Critical Pedagogy. Primary Education.

RESUMO - Pensamento Crítico e Desafios na Educação para a Cidadania Democrática: um estudo etnográfico em escolas de ensino fundamental na Grécia. Este artigo relata um estudo etnográfico de caso múltiplo na Grécia. Examina as práticas docentes relacionadas à educação de cidadãos com pensamento crítico dez anos após a implementação de uma reforma integrada do currículo. Por meio de observações em sala de aula e entrevistas semiestruturadas, esta pesquisa examinou o papel do pensamento crítico nas salas de aula. Os achados sugerem que os professores evitam as práticas que promovem habilidades em pensamento crítico e o empoderamento dos estudantes. Ao contrário, tendem a implementar práticas tradicionais, sendo seu trabalho determinado, em grande parte, pelos padrões de aproveitamento definidos pelo vestibular e pelas aspirações dos pais. $\mathrm{O}$ artigo conclui que as expectativas prevalentes no ensino fundamental grego interferem no desenvolvimento de relações pedagógicas que promoveriam o pensamento crítico, obstruindo o alcance dos objetivos da reforma integrada do currículo e comprometendo o projeto para a cidadania democrática.

Palavras-chave: Pensamento Crítico. Cidadania Democrática. Prática Pedagógica. Pedagogia Crítica. Ensino Fundamental.

Educação \& Realidade, Porto Alegre, v. 43, n. 3, p. 865-886, July/Sept. 2018. 865 http://dx.doi.org/10.1590/2175-623674799 
Critical Thinking and Challenges for Education for Democratic Citizenship

\section{Introduction}

This paper reports on an ethnographic multiple case study research conducted in five primary schools in Greece aiming to document the role of critical thinking in everyday practices in school and its intertwining with the teaching and practices for democratic citizenship. The theoretical premise of the research lies on the critical importance of critical thinking for the development of democratic citizenship in school. Educational research conducted during the 1980s is associated with the development of critical thinking as essential for developing the ability to participate in a democratic inclusive society (Walters, 1994), while over the course of the past three decades critical thinking has been included in educational programmes and curricula around the world (Hamers; Overtoom, 1997).

But what is critical thinking? From the perspective of philosophy, critical thinking has been associated with the concept of reason and the idea of rationality, and it has been understood as "good thinking" (Groarke; Tindale; Little, 2013, p. xiii). Within the field of psychology critical thinking has been conceptualised as "[...] higher order thinking" (Halpern, 1998, p. 451).

On the other hand, proponents of Critical Pedagogy define it as the capacity to recognise and overcome social injustices (Giroux, 1994; McLaren, 1994). Ten Dam and Volman (2004, p. 360) adopting a critical perspective to the concept of citizenship and its relationship to critical thinking argue:

[...] nowadays people are not expected to 'know their place' but to 'determine their own position'. A 'critical' approach is frequently appreciated more than subservient accommodation. It is a question of making choices and knowing why you are making that choice, respecting the choices and opinions of others, communicating about these, thereby forming your own opinion, and making it known. Of course, the extent to which a 'critical' approach is valued and by whom differs.

Thus critical thinking has been identified as essential for democracy which requires people to take responsibility for their own reasoning and develop dialogue in an atmosphere of mutual respect for reason (Nussbaum, 2006). In this article I argue in favour of the critical role of critical thinking as championed from the perspective of Critical Pedagogy in that it promotes a democratic conscience and a transformative, pluralistic civic standard premised on the pedagogical principles of dialogue and inclusiveness.

\section{Critical Thinking and Education for Democratic Citizenship}

A review of the literature reveals that the aim for education for democratic citizenship has been developed under the heading of critical thinking. A significant number of national and international policy

866 Educação \& Realidade, Porto Alegre, v. 43, n. 3, p. 865-886, July/Sept. 2018 
documents on citizenship education have included critical thinking as an aim for citizenship education. Nevertheless, and despite the formal pronouncements regarding the importance of critical thinking, these documents often present internal inconsistencies or even contradict wider policies that frame them. In the following paragraphs I examine some key citizenship education policy documents in the European context. In particular, I look at the way these documents index critical thinking in relation to democratic education and education for human rights viewing the safeguarding of the latter as a major factor for the sustainability of democratic societies (Osler; Starkey, 2005).

The Recommendation of the Council of Europe on Teaching and Learning about Human Rights in Schools (Committee of Ministers, 1985) enlists a number of skills that are associated with the understanding of human rights through teaching and learning processes. In this list no explicit reference is made to critical thinking as a concept or a skill. However, the latter emerges as a requisite for the processes of teaching and learning for human rights. Critical thinking is presumed an essential element for the achievement of human rights learning and the tackling of racism, since it is directly related to the principles of rationality and reason (i.e. pupils' abilities: "to listen and discuss and to defend one's opinions, to collect material from various sources, including the mass media and the ability to analyse it and to arrive at fair and balanced conclusions, to take responsibility, to participate in decisions, to understand the use of the mechanisms for the protection of human rights at local, regional, European and world levels" p. 2). These principles underpin all of the skills included in the list, also reflecting what was previously defined as the ideal of citizenship.

The International Citizenship and Civics Study (IEA, 2009) examined critical and independent thinking separately from the issues of political participation and the stances towards the Other but in their responses, participants do not associate the two concepts either. This fact highlights a divergent understanding of critical thinking which is also detected in the Recommendation of the Council of Europe on Teaching and Learning about Human Rights. According to this approach, critical thinking is considered both a transferable skill and a social qualification.

Twenty-five years after the Recommendation on Teaching and Learning about Human Rights in Schools, the Council of Europe issues the Charter on Education for Democratic Citizenship and Human Rights Education (EDC/HRE) (Committee of Ministers, 2010), a new document emphasising the importance of the protection of human rights through education. Unlike the Recommendation mentioned above, in the Charter for EDC/HRE there is no explicit reference to critical thinking as a skill to be practiced and cultivated in the pedagogical praxis. There is no other implicit prescriptive guidance provided regarding critical thinking which could assist policy making on national level and the implementation of the aims related to the democratic citizenship and the protection of human rights either.

Educação \& Realidade, Porto Alegre, v. 43, n. 3, p. 865-886, July/Sept. 2018. 
Critical Thinking and Challenges for Education for Democratic Citizenship

The Crick Report in England (1998, p. 44) provides a good example of a national level policy document for citizenship education where critical thinking skills are included amongst these essential elements that pupils should acquire by the end of compulsory education:
- ability to make a reasoned argument both verbally and in writing,
- ability to co-operate and work effectively with others, ability to consider and appreciate the experience and perspective of others,
- ability to tolerate other viewpoints,
- ability to develop a problem-solving approach,
- ability to use modern media and technology critically to gather information,
- a critical approach to evidence put before one and abili- ty to look for fresh evidence,
- ability to recognise forms of manipulation and persu- asion,
- ability to identify, respond to and influence social, mo- ral and political challenges and situations.

To a large extent what is being defined as critical thinking skills in the context of the Crick Report seems to overlap with the skills enlisted for the teaching and learning of human rights. However, the Crick Report is characteristically more moderate and avoids endorsing the notion of participation as a factor that advances critical thinking. It is also notable that in spite the historical context wherein the Report was issued, which included the integration of the European Convention on Human Rights into the legal system, there is a disregard for the protection of human rights (Gamarnikow; Green, 2007). Instead, there are mere references to tolerance of the Other while the Report has also been criticised for its failure to challenge the mechanisms that undermine democracy and democratic citizenship (Osler, 2000).

The approach that the Report adopts towards critical thinking also undermines its main goal which is uttered as follows:

$$
\begin{aligned}
& \text { [...] our goal is to create a nation of able, informed and } \\
& \text { empowered citizens who, on the one hand, know, under- } \\
& \text { stand and can enforce their rights; and on the other, rec- } \\
& \text { ognise that the path to greatest personal fulfillment lies } \\
& \text { through active involvement in strengthening their society } \\
& \text { (QCA, 1998, p. 61). }
\end{aligned}
$$

What is being emphasized here is the concept of empowerment which is a recurring one in the Report and which is compromised due to the benign and rather instrumental way critical thinking is included in the document (Gamarnikow; Green, 2007). 


\section{Democratic Citizenship, Critical Thinking and Critical Pedagogy}

Scholars from the field of Critical Pedagogy emphasise the relationship between democratic citizenship and critical thinking concluding that pupils and democratic citizens need to think critically in order to be able to decipher social inequalities, class struggle and power relations. More specifically, they locate the threat to democracy to contemporary trends of civic illiteracy. Giroux (2015, n. p.) argues: “[...] civic literacy is the bedrock of any democratic society and its decline suggests that totalitarianism has become the crisis of our time".

In the argumentation used by the proponents of Critical Pedagogy in favour of civic education, understanding politics is considered critical for the development of democratic consciousness. Castoriadis (1996, p. 8) clarifies the connection between politics, civic education and democracy stating that "[...] politics has to do with political judgement and value choices". It is, therefore, evident that the understanding of politics through pedagogical processes is a prerequisite for a meaningful, interventional and transformative education.

Following Freire (1993) the understanding of politics begins with the understanding of the politics of the curriculum. Theorists from the field of Critical Pedagogy contend that the hidden curriculum demarcates the limits of conflict and determines the development of critical thinking promoting, at the same time the reproduction of dominant ideologies and the construction of subjectivities through processes of symbolic control (Bernstein, 1991). Therefore, the hidden curriculum (otherwise defined as school culture) contributes to the de-democratisation of education and the transformation of pupils-citizens into subjects of neoliberalism (Pykett, 2010).

Critical Pedagogy offers a theoretical proposal for puzzling out the relationship between power and knowledge. In this theory, pedagogy is perceived as "[...] a deliberate attempt to influence how and what knowledge and indentities [sic] are produced within and among particular sets of social relations" (Giroux; Simon, 1989, p. 239) and it is emphasised that within its limits pupils should be able to recognise what is taken for granted through interventions in ritualistic processes that naturalise existing power relations and codes of the dominant culture (McLaren, 1995; Giroux, 2011).

Theorists from the field of Critical Pedagogy also highlight the crucial role of educators. They stress the fact that teachers should avoid the pitfall of becoming a vehicle for the imposition of symbolic and intellectual violence. Instead they should embrace their responsibility as public intellectuals and envisage education as a democratic project rejecting reductionist definitions of their role which restrict them within the boundaries of the mere delivery of the curriculum.

According to McLaren (1994) critical thinking needs to move beyond mainstream approaches which set reason as their main criterion.

Educação \& Realidade, Porto Alegre, v. 43, n. 3, p. 865-886, July/Sept. 2018. 869 
Critical Thinking and Challenges for Education for Democratic Citizenship

What critical thinkers need to do is to "[...] view thinking as a means of empowerment and reorganisation of human will to the direction of social transformation" (McLaren, 1994, p. 13-14). Critical Pedagogy addresses critical thinking as the means for social change. In the context of this approach critical thinking is perceived as a democratic learning process examining power relations and social inequities. This entails processes like active participation or deliberating on issues related to current affairs, which make pupils think politically in the context of the politics of the curriculum (Benesch, 1993). The political nature of thinking which entails the understanding of the root causes of social problems pertaining to governance and power structures sets as a requisite the questioning of power and of the way knowledge and social structures are legitimated and marks one of the most important theoretical contributions of Critical Pedagogy to democratic education.

\section{Democratic Citizenship Education in the Greek Cross- thematic Curriculum Framework for Primary Education}

In the Greek Cross-thematic Curriculum Framework (integrated curriculum) for Primary Education introduced in 2001 democratic citizenship was featured as a central concept, and critical thinking was included as an empowering quality for the pupils and an ideal for society (Alahiotis, 2001a). The authors of the curriculum argue that critical thinking is mainly fostered in the cross-thematic character of the curriculum and the introduction of programmes like the "Flexible Zone" - a two hours curricular innovation where students and teachers can design, develop and implement projects using cooperative, problemsolving and synergistic methodologies - and "Social and Civic Education” (Alahiotis, 2001b).

The 2001 Curriculum reform has been subject to criticism for the lack of planning and for the abstract character of the concepts employed (Noula; Govaris, 2017). One of the main criticisms it has received regards its ill designed cross-thematic conceptualisation that appears to be contributing to the depoliticisation of the knowledge provided and of the education establishment through its neutral positionality (Noutsos, 2003). In particular, the Flexible Zone, although introduced as a progressivist programme which could contribute to the project of social transformation, has been criticized for being a vehicle for the legitimisation of state educational policies. It is essentially a top-down policy designed to improve the effectiveness of the existing educational system rather than challenge inequitable structures (Grollios; Liampas, 2001).

This study took place ten years into an ambitious reform towards this integrated curriculum and explored the way primary school teachers in Greece understand the concept of critical thinking, the way they perceive their role in promoting it in educational settings and the extent to which everyday pedagogical practices emanating from these conceptualisations contribute to pupils' empowerment. The article examines 
pedagogical practices through the lens of Critical Pedagogy which calls educators to undertake a more active role regarding a critical approach to knowledge and to open a door for pupils' emancipation as citizens.

\section{Empirical Research: research strategy}

The research project is a multiple case study. The data collection methods employed included observation in five Year- 6 classes of five primary schools over the period of a school year and semi-structured interviews with the teachers of the classes where the observation took place. The methodology of the present project draws on Grounded Theory. Therefore, the issues discussed in the present article are generated in the process of non-participant observations and they do not emerge from structured protocols.

A preliminary coding, which was informed by the literature on Democratic Citizenship Education, oriented the focus of the observation on certain aspects of the classroom routine and interaction. The use of interviews was a methodological tool which was built upon the observation data. It sought to explore teachers' perspectives on inconsistencies and pitfalls of the educational practice that regard the promotion of critical thinking in the classroom.

In the following sections teachers' accounts and the data collected from the observation are juxtaposed. What is also being investigated is the way teachers perceive critical thinking and how they approach it practically. Finally, potential implications for democratic education will be explored.

\section{Case Selection}

Participants were selected through a process of purposive sampling. The use of this method was mainly necessitated because of the big variation with regard to teachers' education, experience and mentality across the Greek educational system. The sample included five teachers. The variation of the school sample ensured the variation of the teachers' sample too. Schools were selected on the basis of their socio-economic intake and the urbanisation of the area where they were based. The school sample was comprised by a school in an underprivileged urban area ${ }^{1}$, a rural school ${ }^{2}$, a school in a semi-urban area ${ }^{3}$, a suburban school ${ }^{4}$ and a private school. The selection of different schools produced significant differences in the teachers' sample. This is so because in Greece the appointment of teachers to different schools depends upon to their years in service, as teachers' rights as civil servants increase on the basis of a point system that favours seniority.

In spite of the small number of teachers that participated in the research, the different demographic profiles of the schools ensured a great degree of heterogeneity in the teacher sample (Table 1). This was primarily due to the fact that following the Greek legislation teachers in 
Critical Thinking and Challenges for Education for Democratic Citizenship

Greek state schools are assigned their posts based on their seniority following a point system. Accordingly, all four teachers in the state schools share a common educational qualification coming from a basic twoyear training. However, it was observed that amongst them, the three teachers who are in their early forties and with an average of 23 years in service, had opted for the equalisation of their qualification to a Higher Education degree (Stamelos; Emvalotis, 2001). On the other hand, the teacher in the rural area school who has 33 years in service and who is 57 years old did not choose to do any studies beyond his basic qualifications for the enhancement of his pedagogical background.

The restricted formal pedagogical background was a shared feature between him and the teacher in the private school who lacked any sort of formal training in pedagogy and who additionally had significantly less experience than the other four participants.

Table 1 - Teachers' Sample

\begin{tabular}{|c|c|c|c|}
\hline Sex & School & $\begin{array}{c}\text { Years in } \\
\text { Service }\end{array}$ & \multicolumn{1}{c|}{ Training/Studies } \\
\hline $\mathrm{f}$ & Private & 14 & $\begin{array}{l}\text { Higher education degrees (BA in Greek } \\
\text { literature and MA in linguistics) }\end{array}$ \\
\hline $\mathrm{m}$ & Suburban & 25 & $\begin{array}{l}\text { 2-year teacher training academy and } \\
\text { teaching certificate equalisation to } \\
\text { H.Ed. degree }\end{array}$ \\
\hline $\mathrm{m}$ & $\begin{array}{c}\text { Urban } \\
\text { 60\% Roma pupils enrol- } \\
\text { ment }\end{array}$ & 21 & $\begin{array}{l}\text { 2-year teacher training academy and } \\
\text { teaching certificate equalisation to } \\
\text { H.Ed. degree }\end{array}$ \\
\hline $\mathrm{m}$ & $\begin{array}{c}\text { Semi-urban } \\
\text { nearest city from the } \\
\text { ment rate of pupils of } \\
\text { migrant background) }\end{array}$ & 22 & $\begin{array}{l}\text { 2-year teacher training academy and } \\
\text { teaching certificate equalisation to } \\
\text { H.Ed. degree }\end{array}$ \\
\hline $\begin{array}{c}\text { Rural } \\
\text { 40 km. away from the } \\
\text { nearest city (30\% enrol- } \\
\text { ment rate of pupils of } \\
\text { migrant background) }\end{array}$ & 33 & 2-year teacher training academy \\
\hline
\end{tabular}

Source: Author's elaboration.

\section{Observation}

Observation can be considered a useful tool for the exploration of the development critical thinking in educational settings, as it provides the opportunity to investigate aspects of the hidden curriculum. Hidden curriculum is defined as the sum of moral and regulative discourses, which assist to the direction of shaping citizens in the context of schooling (Apple, 2004; Thornberg, 2009; Giroux; Penna, 1983).

However, according to Thornberg (2009), very often the hidden curriculum undermines the goals of citizenship education in the everyday practice overemphasising rules at the expense of critical think- 
ing and democratic education and distinguishing the normal from the deviant. Pedagogy, which lies at the heart of the hidden curriculum, is an essential component within the limits of observation in order to decipher the processes encompassing critical thinking. Consequently, following Simon's (1992, p.140) definition of pedagogy the observation was oriented towards the understanding of "[...] how a teacher's work within an institutional context specifies a particular version of what knowledge is of most worth, what it means to know something and how we might construct representations of ourselves, others, and our physical and social environment".

The codification of the data obtained from the observation and the data analysis were underpinned by the approach of Critical Pedagogy to critical thinking. Accordingly, there was a focus on the construction of meanings and realities, the silences, the regulation via ritualisation and teaching practices and the degree of politicisation of citizenship (Frazer, 2007; McLaren, 1988).

Following the methodology of the project, upon completion of the observation, the material was studied, and the data collected from each school were grouped into categories (i.e., critical ability, evaluation, diversity, rituals, current affairs, rules). The data were then further organised into new subcategories (i.e. otherness: a) the other in the classroom; b) approaches to otherness in the context of the lesson; c) i. the Turk as the Significant other; ii. The European citizen as the Other). Following the principles of thematic analysis (Braun; Clarke, 2008) the categorised data were later revisited and grouped into themes so as to tell a story about what happens in the classroom.

\section{Interviews}

By means of semi-structured interviews with the teachers' the research explored their understanding of critical thinking and its role in the pedagogical process. I was interested in investigating the role of teachers' pedagogical background in the way they understand, and they promote critical thinking in their teaching. Therefore, the interviews included questions regarding teachers' professional development and it covered topics related to their professionalism (motivation, commitment to task etc.) their relationship with other reference groups in the school community etc. Examining critical thinking as an essential intercultural competence and a lever for democratisation, I also looked into their understanding of democracy and inclusivity in education asking questions concerning their understanding of otherness, their strategies for inclusion and the way they conceptualise childhood. Finally, I sought to explore how they value citizenship education as a subject area and a practice examining how they relate it to the curriculum objectives that advocate the standard of the critical thinking citizen and juxtaposing their answers to their actual practices.

Educação \& Realidade, Porto Alegre, v. 43, n. 3, p. 865-886, July/Sept. 2018. 
Critical Thinking and Challenges for Education for Democratic Citizenship

\section{Findings}

In the following sections I am presenting a nexus of factors that have been evaluated as determinants of the school culture of each case studied. Using ilustrative examples from the everyday practices of each school I evidence how elements of the school culture (including staff room atmosphere, teachers' professionalism and behaviour, individual school features and adequacy of infrastructure, teacher-pupil relationships, school activities and other collective action, decoration, morning assembly, prayer etc.) frame pedagogy. Findings from the teachers' interviews are used to shed light and further explicate why and how critical thinking is promoted or hindered in the context of daily practice in school in the light of an integrated curriculum that sets democratic citizenship as its main objective.

\section{Parents' Aspirations and Teachers' Practices: "Parents always expect you to deliver the curriculum and stick to the contents of the textbook"}

The teacher in the rural school argues that pupils in the village cannot develop their talents because of existing stereotypes. Parents are often afraid that they might be subject of criticism by the local society. He further explains that these attitudes influence his professional choices: "For instance; I want to make some more time for Religious Education. I am not able to do that because some of the parents may say: 'Do you need to do this? What will they get from Religious Education?"'

In a similar way the teacher in the semi-urban area school mentions that she feels accountable to parents. She argues that this is the reason why when she assigns group work she feels that it requires too much time compared to the goals she has set in order to meet parents' expectations. She claims: "Parents always expect you to deliver the curriculum and stick to the contents of the textbook".

According to the teachers in the two inner city schools (urban and suburban school), parents display similar expectations. They pursue better performance and achievement for their children and they try to achieve these goals increasing their demands towards teachers. The emphasis given on school performance, as well as on its impact on teachers' work manifest more explicitly in the schools that admit pupils from higher socio-economic strata. The teacher in the suburban area school mentions that the importance attributed by parents to their children's performance and their success to University Entrance Exams influences his work: "I feel that I am under constant criticism..." Moreover, he argues that parents' socio-economic background is very important, as it is related to their educational capital and, therefore, to their involvement to their children's education: "When I am in this classroom I don't know whether I deal with the pupils or if someone else is behind them..." 
The phenomenon described by the teacher in the suburban area school manifests in a more intense way in the private school. In this case, parents' expectations are communicated to the teachers by the school owners who decide upon the adaptation of the curriculum content. In the case of the private school, the teacher's credentials give her the right to teach in a private primary school but, as she states, she feels that she would have felt much more confident in the classroom if she had a pedagogical background. Nevertheless, her specialisation in the subjects like Greek language and history was the main criterion for her being hired given the orientation of the school to pupils' eventual success in the University Entrance Exams. She notes: "I have always felt that I was confined within the limits of delivering the curriculum. I never felt that I could take initiative in the classroom or follow a certain plan. Children always had so much to do, and my time was so limited..."

\section{University Entrance Exams: "I think that University Entrance Exams hold a catalysing role for the educational system and my work"}

Teachers' narratives reveal that parents, already from the first years of children's attendance of primary school, aim at their children's success in the University Entrance Exams. Teachers argue that these exams constitute a factor that shapes their teaching practices and influences their professional choices overall. The teacher in the semi-urban area school made the following statement: "I think that University Entrance Exams hold a catalysing role for the educational system and my work".

The teacher in the private school expressing her views on the same issue mentions: "I don't think that the educational system puts emphasis on critical thinking, since, already from primary school, we take an orientation towards University Entrance Exams”. However, as opposed to her colleague in the semi-urban area school, she argues in favour of the fact that the school where she works focuses almost exclusively on University Entrance Exams: "This way children are better prepared for the University!"

The teacher in the rural area school maintains that one of the most crucial problems of the Greek educational system is the lack of coherence and the absence of continuity in between the different levels in education. He suggests that the best solution to this problem would be the emphasis on the teaching of Greek Language and Writing and the good study of Mathematics so that pupils will be adequately prepared for the subsequent levels.

The fact that teachers tend to adjust to parents' expectations compromises the democratic character of the school as a locus of democratic dialogue and equal participation of all reference groups of the school community. Teachers as well as the pupils who are the main actors in the pedagogical processes they are kept within the limits of parents' aspirations. For teachers this restraint on the pedagogical relationship 
Critical Thinking and Challenges for Education for Democratic Citizenship

manifests as parents' vested interest towards their children, while for children these expectations constitute another manifestation of their parents' authority and its impact on the shaping of their subjectivity.

The pursuit of high performance and the emphasis on achievement, as a factor of social mobility, results to pedagogical relationships which in Bernstein's terms are shaped in the context of strong framing regarding the transmission of knowledge and which are therefore characterised by asymmetries. According to Bernstein (1991) "[...] the strongest the classification and framing, the more hierarchical and ritualistic the educational relationship tends to be, the trainee is considered ignorant with little authority and a few rights" (1991, p. 83).

\section{Parents' Aspirations and its Impact on Teachers' Attitudes and their Collaboration}

According to teachers, the implementation of activities of integrated character (i.e. projects) could improve their relationship with their colleagues; it could enrich their professional experience and therefore be particularly useful for pupils.

They argue that the existing lack of cooperation amongst colleagues is due to two reasons. Firstly, it is related to the role of the parents as a reference group in the school community and hence the fact that they regard pupil performance as the most important part of the educational process. Secondly, lack of cooperation results from the attitudes that teachers adopt at school and the strategies that they deploy because of parents' orientations described above.

In the interviews, public school teachers maintain that they could have benefited from cooperation with colleagues. However, according to them, their colleagues usually avoid sharing their experiences out of fear that they may be judged as inadequate. The teacher in the suburban school contends that his colleagues in the school prefer to implement traditional teaching practices that parents consider most effective for delivering the curriculum, mainly because "[...] they care very much about their profile".

As documented in the observation, public school teachers' work is limited within the confines of their classroom and it is restricted to the collaboration with the pupils, while cooperation with their colleagues is of a purely social character. In some cases, it becomes very clear that teachers enjoy the sociability offered by their profession, as in the case of school suburban area. The private school is differentiated with respect to the issue of cooperation of teachers. Although in this case the teachers still do not cooperate, however, what distinguishes them from their colleagues in public schools is the lack of social relationships and their commitment to the subject of teaching. According to Bernstein, staff relations are indicative of a school's democratic function and of the weak horizontal relationships that are being developed in the lower scales of the hierarchy (staff) because of the centralised governance of private institutions.

876 Educação \& Realidade, Porto Alegre, v. 43, n. 3, p. 865-886, July/Sept. 2018. 


\section{Teacher-Centred Practices and School Knowledge}

During the observation, teachers' preference for traditional teaching methods (i.e. verbalism and memorisation) was documented. It was only the teacher in the semi-urban area school that at times attempted to assign group work. However, she too had to quickly wrap-up and move on with traditional practices in order to stay within the timeframe. The teacher in the underprivileged urban area school added group work in his teaching methods repertoire in the middle of the school year, while in the rural area school pupils used to sit in groups for practical reasons, without, however, being assigned any cooperative work. The teacher of the rural area school was adopting traditional teaching methods. During the class he used to sit behind is desk, and he would rarely converse with the pupils or take into account their opinion. Instead, he was often using sarcasm to challenge them.

With regard to pupils' assessment it should be noted that many similarities amongst different schools were observed, while assessment itself constituted another dimension of ritualisation of pupils' life in school. Each morning pupils were examined in spelling. This practice was followed by the assessment of their homework. The assessment of written work was often followed by oral or written tests on different subjects. What should be brought in to attention is that in the private school excessive emphasis was given on the practices of memorisation and written examinations. Pupils followed the requirements of the school trying to achieve the best grades and high performance in general, setting University Entrance Exams as a model of operation and an ideal.

The processes of assessment along with practices of discipline and the daily rituals that make up the school culture contribute to the naturalisation of social order. Teaching practices in particular relate to the construction of codes at the level of human relationships between teachers and pupils. It seems that these practices establish a model of relationships whose feature is that of hierarchisation of relationships based on the concept of authority and, therefore, the dichotomisation and hierarchical arrangement of roles between knowledgeable (teachers) and the unknowledgeable (pupils).

The teaching practices described above that are premised on the distinction between useful knowledge for the development of the individual and non-useful knowledge which corresponds to secondary subjects in the curriculum, eventually subdue individual development to a market logic of the development of human capital. It was also documented in all cases that the subject of Social and Political Education falls in the category of insignificant knowledge since it was classified as a secondary subject. This fact was undermining the importance of its content and the value of deliberation for the position of the pupil as a citizen in the social world. 
Critical Thinking and Challenges for Education for Democratic Citizenship

\section{Relationships Between Teachers and Pupils}

The extent of asymmetry and the hierarchical structure of teacher-pupil relationships became evident in other aspects of the pedagogical relationship. Clearly, the young teacher in the private school was finding it difficult to communicate with pupils. She was trying to establish her authority raising the tone of her voice, addressing boys with their last name, threatening, or using sarcasm. It is interesting that the teacher in the rural area school, with 33 years teaching experience, was using similar practices (i.e., he constituted the sole source of authority in the classroom and he was using sarcasm as the main instrument for class management). His behaviour towards the pupils was discouraging regarding their performance or their potential and, thus, they were often reluctant to answer his questions.

In the other three schools of the sample, despite the fact that teachers were the ones who were the sole source of authority in the classroom, they were more open to discussions and more tolerant to any inappropriate pupil behaviour.

This condition, which is common for all three of the five schools of the sample, was critical for pupils' education, and although it did not encourage their participation it was revealing nonetheless of the acceptance of pupils' personalities and it was leaving room for initiative from their part.

With regard to dialogue between teachers and pupils, the issues treated in class regarded mainly events from everyday life in school (i.e. an argument between pupils, a pupil's behaviour). According to the observation, only two teachers in city schools elaborated the everyday conversation covering topics concerning current affairs. The teacher of the school of the underprivileged urban area had three detailed discussions with pupils about the reasons for the economic crisis in Greece during which pupils were given the opportunity to express themselves and give their interpretation of the phenomenon. On the other hand, the teacher in the suburban area school, whenever opportunities arose, used to comment upon the content of the textbooks, the educational policies and he used to talk to pupils about the hidden messages they include or about their propagandistic character. However, even in his case, very rarely there was room for discussion or interaction wich would allow pupils to express their opinions.

\section{Teachers' Approaches to Critical Thinking}

When critical thinking emerges as an issue in the interviews, most teachers associate it with the cross-thematic character of the curriculum (DEPPS ${ }^{5}$ ) or the integrated activities proposed in the Flexible Zone programme. Teachers who mention these concepts and make explicit references to the concept of critical thinking are those of both urban area schools and school of the semi-urban area. As mentioned above, these teachers have a common educational background in terms

878 Educação \& Realidade, Porto Alegre, v. 43, n. 3, p. 865-886, July/Sept. 2018. 
of their education and have almost the same number of years in service in education.

These teachers mention that cross-thematic activities proposed by the curriculum - especially those related to the Flexible Zone where pupils can work on different projects - can contribute to the development of critical thinking. According to the teacher in the urban area school, these activities can also contribute to the improvement of teacher-pupil relationships. The teacher in the underprivileged urban area school highlights the importance of these activities, their contribution to the development of pupils' ability to learn how to learn (metacognitive competence) which is another central concept in the curriculum for primary education and which is closely linked to the idea of lifelong learning. Finally, the teacher in the semi-urban area school uses the example of group work which she considers the main way of implementing cross-thematic activities. She argues that group work helps pupils think creatively and encourages them to participate. Her colleague in the urban area school believes that working in groups favours the relationships between teacher and pupils, and he maintains that in this context, teachers have the opportunity to teach values and principles such as mutual respect and responsibility.

Juxtaposing teachers' answers to their teaching practices and the content of the curriculum it appears that critical thinking acquires an almost fetishistic character in their narratives. It becomes clear that during the interviews teachers emphasise the importance of the development of critical thinking in pupils. However, these answers are of rather tautological content since they associate critical thinking with the terminology and the methodology suggested by the Curriculum. The concept of critical thinking is not being approached as a way of life that translates into teaching practice in order to empower pupils, but it rather regards a number of skills with instrumental character, such as those of writing and reading.

\section{Teachers' Training and Pedagogical Practices}

Data from the interviews and the observations reveal a dichotomy in the teachers' sample. The dichotomy concerns the orientation of the practices (progressive or traditional) that teachers endorse in their narratives. The data analysis shows that the teachers in the rural area and the private schools, despite significant differences in terms of their educational capital, age, and years in service and their contrasting experience regarding their working environments, display a convergence with regard to the teaching methods they adopt and the model of relationship they develop with the pupils, whom they approach in a similar manner and utilising the same methods of classroom management.

On the other hand, the other three teachers of the sample who have very similar qualities (years in service, education, age, working environment experiences) exhibit a tendency to implement or express 
Critical Thinking and Challenges for Education for Democratic Citizenship

their endorsement for more progressive pedagogical practices. In the interviews they raise the importance of group work for the relationship between the pupils and the teacher, while one of them raises the significance of the need for Open Curricula.

Interestingly, teachers in the private school and the rural area school, despite their very different professional profile, they share similar views regarding the importance of pupils' performance and achievement in school in general. They also share a concern that makes them try to balance between their view that school should be preparing responsible, critically thinking citizens and their approach to primary school as a preparatory stage for Higher Education.

The same dichotomy arises for a second time in the teachers' sample and it appears to be related to the issue of critical thinking which is central to the discussion on citizenship education. Interview data analysis shows that the teachers in the private and the rural area schools emphasise the importance of performance and the significance of University Entrance Exams and they downgrade or ignore the importance of the development critical thinking. Although in the cases of the other teachers the praxis of teaching has shown that major problems hamper the advancement of critical thinking, the recognition of the importance of the latter is yet another sign of their effort to establish pedagogy on a progressive basis.

This dichotomy emerging in the teachers' sample assists towards understanding the key role of teacher education and the acquirement of a strong pedagogic background for the development of dialogical teacher-pupil relationships and the shaping of pupils' political subjectivity through participatory processes and the exercise of critical thinking.

The binding character of the curriculum emphasised by teachers, its rigidity which is heightened by parents' aspirations, and the prevailing mentality about the role of primary education which is seen as a preparatory stage for University Entrance Exams constitute an advantage for pupils in the private school where the curriculum content, the aims and the methodology suggested are customised in order to meet the parents' expectations. On the other hand, it becomes clear that teachers have enough room to change their educational strategies despite the limitations they describe. These changes could take the form of the alteration of assessment methods (e.g. focus on understanding), the adoption of a critical approach to the content of the curriculum, the use of engaging examples resonating with the daily life of pupils and their engagement in dialogical relationships with pupils which would allow both parties to actively participate, negotiate meanings and construct knowledge. 


\section{Everyday Pedagogy and the Curriculum: "There are many inconsistencies between theory and practice"}

In teachers' narratives the curriculum emerges as a factor that further limits their choices and impedes their educational work. The teacher in the semi-urban area school says: "There are many inconsistencies between theory and practice". She points out that although one of the main objectives of the curriculum is the cultivation of critical thinking by developing pupils' ability to learn how to learn, however, at the end of each term teachers have to grade pupils.

Teachers in the two inner-city schools and the rural area school emphasised two other aspects of the curriculum that define the nature of their work. They referred to its extensiveness and its centralised character. In particular, the teacher in the rural area school explained that it is not possible for teachers in one-teacher schools in rural areas to adjust the school curriculum to pupils' needs (he teaches Year 5 and Years 6 pupils in the same classroom). Therefore, these teachers' time is significantly limited and so they are forced to focus on the so-called main subjects. The teacher in the underprivileged urban area school makes a similar observation. According to the teacher in the rural area school, due to time constraints, Greek Language and Mathematics are the subjects where emphasis is given as they are considered the most critical for pupils' preparation for the University Entrance Exams. The teacher in the urban area school argues that the volume of the curriculum content for the main subjects is large and there is never enough time for the proper teaching of other subjects.

Apparently, all teachers of the sample make a knowledge-centred interpretation of the Cross-thematic Curriculum Framework. This approach appears to be impeding the implementation of the objectives regarding the "development of critical thinking" (Ministry of Education and Religious Affairs, 2001, p. 8) and "the multifaceted development of pupil's personality in the natural and social environment" (p. 2) as suggested by the guidelines of the Curriculum. However, the teachers who endorse progressive approaches to pedagogy acknowledge their inadequacy to assist towards the achievement of the objectives set by the Curriculum. In contrast, their colleagues in the rural area and the private schools always emphasise the importance of teaching the subjects of Grammar and Mathematics.

\section{Conclusions}

The findings suggest that in the Greek primary school democratic citizenship is challenged by mentalities and practices that hamper the development of pupils' critical thinking, by the denial of pluralism, the exclusion of reference groups from the participatory processes and, finally, by the failure to recognise the forces that shape power relations and the content of knowledge. 
Critical Thinking and Challenges for Education for Democratic Citizenship

The adopted teaching practices and the ensuing pedagogical relationships place pupils in a disadvantaged position and subordinate them to the authority of the teacher and the dominance of curriculum discourses. The subversion of the project for the implementation of integrated curriculum in the Greek classroom through teacher-centred practices that weaken pupils' critical thinking further undermines the attainment of the aim for tomorrow's active citizenship as defined in the text of the Cross-thematic Curriculum Framework for Primary Education.

Instead, the conditions induced suggest that pupils in the Greek primary school are not recognised as equal partners either inside or outside the classroom, they are not taken into account in decisionmaking processes and they are taught that political participation is an obligatory right which is limited to their participation in the processes of the election of pupil councils that possess nominal powers. Ritualistic practices that revolve around the axis of discipline instil the dominant cultural and political codes excluding students from participatory or deliberative processes. This form of exclusion eventually produces a norm of withdrawal from the political (Noula, 2014).

Finally, the findings show that the school functions as a locus of human capital production emphasising teaching subjects and methods that favour capitalist production and drive away from the logic of the deliberation and pluralism. Instead, they prepare "[...] students for the world as it is” (Freire, 1993; McAvoy; Hess, 2013, p. 15).

Findings indicate that the Greek primary school serves further the imperatives of neoliberalism mainly because of inadequate teacher education and pedagogical orientation, thus reproducing the status quo and increasing the asymmetry between the upper and lower socioeconomic strata. Hyslop and Sears (2006) explain that such conditions naturalise the logic of neoliberalism suggesting that there is no alternative. The emergence of this political conformism engenders the decline of democracy and the transition to a consumerist model of citizenship.

The emphasis placed on University Entrance Exams is the major factor that inhibits the democratic dynamic of the Greek primary school. This is because the linear character of the Greek educational system constitutes an advantage for pupils from higher socio-economic strata who are rewarded socially and culturally from this educational model, which tends to reproduce the discourses of the status quo.

Parental involvement and the dichotomy emerging in the teachers' sample in terms of the importance they attribute to pupils' performance raise questions about the myth that the social divisions could be abolished by means of a democratic educational system. In the private and the rural area schools teachers' tautological definitions about critical thinking (critical thinking means being able to think critically) and their endorsement of performance orientated practices reveal the reproduction of the ideological convergence of those belonging to the (upper) middle class and have nothing to lose from the perpetuation of

882 Educação \& Realidade, Porto Alegre, v. 43, n. 3, p. 865-886, July/Sept. 2018. 
the current economic system on the one hand, and those coming from lower socio-economic backgrounds (Tsoukalas, 2006). Under these circumstances, pupils of migrant background find themselves in a more disadvantaged position due to their deficient economic capital, their differentiated cultural background or the ignorance of communication repertoires in educational settings (elaborated codes).

Received on July 06,2017 Approved on November 20, 2017

\section{Notes}

1 The living standards of the people residing in the area is largely shaped by its geographical configuration which impedes their access to the city centre and it is affected by the fact that in the school under examination the Roma pupils' enrolment reaches $60 \%$ while for the majority of the schools in the city the average is $4 \%$.

2 The school is situated in a rural area $40 \mathrm{klm}$. away from the nearest city (30\% enrolment rate of pupils of migrant background).

3 The school is situated in a small town $12 \mathrm{klm}$. away from the nearest city (15\% enrolment rate of pupils of migrant background).

4 The school is located in a rapidly growing suburb of the city with middle class and upper middle-class families.

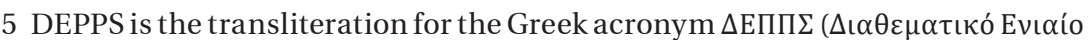

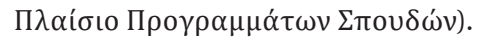

\section{References}

ALAHIOTIS, Stamatis. Cross-thematic Curriculum Framework and Curricula for Compulsory Education. Athens: Ministry of Education and Religious Affairs, 2001a. Available at: <http://www.pi-schools.gr/download/programs/ depps/prologos.pdf $>$. Accessed on: 18 Mar. 2016.

ALAHIOTIS, Stamatis. Cross-thematic Curriculum and Flexible Zone Change Education and Upgrade the Quality of Education. Athens: Ministry of Education and Religious Affairs, 2001b. Available at: <http://www.pi-schools.gr/ download/programs/depps/s_alax_diathematikotita.pdf $>$. Accessed on: 18 Mar. 2016.

APPLE, Michael. Ideology and Curriculum. New York: Routledge Falmer, 2004. BENESCH, Sarah. Critical Thinking: a learning process for democracy. Tesol Quarterly, London, v. 27, n. 3, p. 545-548, 1993.

BERNSTEIN, Basil. Pedagogical Codes and Social Control. Athens: Alexandria, 1991.

BRAUN, Virginia; CLARKE, Victoria. Using Thematic Analysis in Psychology. Qualitative Research in Psychology, London, v. 3, n. 2, p. 77-101, 2008.

CASTORIADIS, Cornelius. Institution and Autonomy. In OSBORNE, Peter: A critical sense: interviews with intellectuals. London; New York: Routledge. 1996.

Educação \& Realidade, Porto Alegre, v. 43, n. 3, p. 865-886, July/Sept. 2018. 
Critical Thinking and Challenges for Education for Democratic Citizenship

COMMITTEE OF MINISTERS. Recommendation n. R (85) 7 of the Committee of Ministers to Member States on Teaching and Learning about Human Rights in Schools. Strasbourg: Council of Europe Publishing, 1985.

COMMITTEE OF MINISTERS. Recommendation CM/Rec (2010) 7 adopted by the Committee of Ministers of the Council of Europe on 11 May 2010 and explanatory memorandum. Strasbourg: Council of Europe Publishing, 2010.

FRAZER, Elizabeth. Depoliticizing Citizenship. British Journal of Educational Studies, London, v. 55, n.3, p. 249-263, 2007.

FREIRE, Paulo. Pedagogy of the Oppressed. London: Penguin Books, 1993.

GAMARNIKOW, Eva; GREEN, Anthony. Social Capital and the Educated Citizen. The School Field, London, v. 10, p. 103-126, 1999.

GIROUX, Henry. Toward a Pedagogy of Critical Thinking. In: WALTERS, Kerry. Re-thinking Reason: new perspectives in critical thinking. Albany: State University of New York Press, 1994.

GIROUX, Henry. On Critical Pedagogy. New York: Continuum International Publishing Group, 2011.

GIROUX, Henry. Political Frauds and the Ghost of Totalitarianism. Truthout, online, 2015. Available at: <http://www.truth-out.org/news/item/32800-political-frauds-and-the-ghost-of-totalitarianism>. Accessed on: 15 Mar. 2016.

GIROUX, Henry; PENNA, Anthony. Social Education in the Classroom: the dynamics of the hidden curriculum. In: GIROUX, Henry; PURPEL, David (Org.). The Hidden Curriculum and Moral Education. California: McCutchan Publishing Corporation, 1983. P. 100-121.

GIROUX, Henry; SIMON, Roger. Popular Culture and Critical Pedagogy: everyday life as a basis for curriculum knowledge. In: GIROUX, Henry; MCLAREN, Peter (Org.). Critical Pedagogy, the State, and Cultural Struggle. New York: SUNY, 1989.

GROARKE, Leo; TINDALE, Christopher; LITTLE, Frederick. Good Reasoning Matters!: a constructive approach to critical thinking. Don Mills, Ontario: Oxford University Press, 2013.

GROLLIOS, Giorgos; LIAMPAS, Tasos. Flexible Zone and Project Method. Ekpedeftiki Kinotita, online, v. 60, 2001.

HALPERN, David. Teaching Critical Thinking for Transfer across Domains: dispositions, skills, structure training, and metacognitive monitoring. American Psychologist, Washington, DC, v. 53, p. 449-455, 1998.

HAMERS, Jo; OVERTOOM, Md. Teaching thinking in Europe: inventory of European programmes. Utrecht, the Netherlands: Sardes. 1997.

HYSLOP-MARGISON, Emery; SEARS, Alan. Neo-Liberalism, Globalization and Human Capital Learning: reclaiming education for democratic citizenship. Dordrecht: Springer, 2007.

McAVOY, Paul; HESS, Diana. Classroom Deliberation in an Era of Political Polarization. Curriculum Inquiry, Chicago, v. 43, n. 1, p. 14-47, 2013.

McLAREN, Peter. Foreword. In: GIROUX, Henry. Teachers as Intellectuals: toward a critical pedagogy of learning. Granby, Mass: Bergin \& Garvey, 1988. P. 9-23.

McLAREN, Peter. Critical Thinking as a Political Project. In: WALTERS, Kerry. Re-thinking Reason: new perspectives in critical thinking. Albany: State University of New York Press, 1994.

884 Educação \& Realidade, Porto Alegre, v. 43, n. 3, p. 865-886, July/Sept. 2018. 
McLAREN, Peter. Critical Pedagogy and Predatory Culture: oppositional politics in a postmodern era. London; New York: Routledge, 1995.

MINISTRY OF EDUCATION AND RELIGIOUS AFFAIRS. Cross-thematic Curriculum Framework and Curricula for Compulsory Education. General Part [online]. Athens, 2001. Ministry of Education and Religious Affairs. Available at: $<$ http://www.pi-schools.gr/download/programs/depps/prologos.pdf $>$. Acessed on: 25 Mar. 2018.

NOULA, Ioanna. The Concept of Citizenship in Primary Education in Greece: the construction of the concept of citizenship in the context of pedagogic practices. Volos: University of Thessaly, 2014.

NOULA, Ioanna; GOVARIS, Christos. Neoliberalism and Pedagogical Practices of Alienation: a case study research on the integrated curriculum in Greek primary education. British Journal of Educational Studies, London, p. 1-22, 2017.

NOUTSOS, Babis. Cross-thematic Curriculum Framework: the ideology of "ahtarma". Ekpedeftiki Kinotita, online, v. 67, p. 24-29, 2003.

NUSSBAUM, Martha. Education and Democratic Citizenship: capabilities and quality education. Journal of Human Development, London, v. 7, n. 3, p. 385395, 2006

OSLER, Audrey. The Crick Report: difference, equality and racial justice. The Curriculum Journal, London, v. 11, p. 25-37, 2000.

OSLER, Audrey; STARKEY, Hugh. Changing Citizenship: democracy and inclusion in education. New York: Open University Press, 2005.

PYKETT, Jessica. Citizenship Education and Narratives of Pedagogy. Citizenship Studies, London, v. 14, n. 6, p. 621-635, 2010.

QCA QUALIFICATIONS AND CURRICULUM AUTHORITY. Education for Citizenship and the Teaching of Democracy in Schools: final report of the advisory group on citizenship (the Crick Report). London: QCA, 1998.

SIMON, Roger. Empowerment as a Pedagogy of Possibility. In: SHANNON, Patrick. Becoming Political: readings and writings in the politics of literacy education. Portsmouth, NH: Heinemann, 1992.

STAMELOS, Georgios; EMVALIOTIS, Anastasios. Exploring the Profile of Departments of Education. Scientific Annals Department of Primary Education University of Ioannina, Janina, n. 14, p. 281-292, 2001.

TEN DAM, Geert; VOLMAN, Monique. Critical Thinking as a Citizenship Competence: teaching strategies. Learning and Instruction, Amsterdam, v. 14, n. 4, p. 359-379, 2004

THORNBERG, Robert. The Moral Construction of the Good Pupil Embedded in School Rules. Education, Citizenship and Social Justice, London, v. 4, n. 3, p. 245-261, 2009.

TSOUKALAS, Constantinos. Dependence and Reproduction: the social role of education in Greece (1830-1922). Athens: Themelio, 2006.

WALTERS, Kerry. Re-thinking Reason: new perspectives in critical thinking. Albany: State University of New York Press, 1994. 
Critical Thinking and Challenges for Education for Democratic Citizenship

Ioanna Noula received her $\mathrm{PhD}$ on citizenship education from the University of Thessaly in 2015. She is currently a researcher at the UCL Institute of Education and a Visiting Fellow in the Department of Media and Communications of the London School of Economics where she currently investigates the topic of digital citizenship education. She has also worked as a teacher in primary schools in Greece and in the UK. Her research interests include citizenship education, critical pedagogy, digital living, sustainability and social justice.

E-mail: i.noula@lse.ac.uk

This is an open-access article distributed under the terms of the Creative Commons Attribution License 4.0 International. Available at: $<$ http://creativecommons.org/licenses/by/4.0>. 